\title{
APPLICATION OF INSTRUMENTATION AND CONTROL SYSTEM FOR BIOGAS POWER GENERATION COMMISSIONING AT PTPN V KAMPAR PALM OIL MILL
}

\section{APLIKASI SISTEM PENGUKURAN DAN KONTROL PADA UJI COBA PEMBANGKIT LISTRIK TENAGA BIOGAS DI PABRIK KELAPA SAWIT PTPN V KAMPAR}

\author{
Arya Bhaskara Adiprabowo ${ }^{a}$, Bambang Muharto ${ }^{a}$, Hana Nabila Anindita ${ }^{a}$, Nur Azimah \\ Salehah $^{\text {b }}$, Dwi Husodo Prasetyo ${ }^{\text {a }}$, Semuel Pati Senda ${ }^{a}$, Muhamad Rodhi Supriyadia, Nesha \\ Adelia $^{a}$, Bayu Samodra ${ }^{c}$ \\ a Pusat Teknologi Sumberdaya Energi dan Industri Kimia, BPPT \\ ${ }^{b}$ Balai Besar Teknologi Kekuatan Struktur, BPPT \\ ${ }^{\mathrm{c}}$ Balai Besar Teknologi Konversi Energi, BPPT \\ Gedung 625, 620, 621, Kawasan Puspiptek Serpong, Tangerang Selatan, Indonesia \\ e-mail: arya.bhaskara@bppt.go.id, bambang.muharto@bppt.go.id, hana.nabila@bppt.go.id, \\ nur.azimah@bppt.go.id,dwi.husodo@bppt.go.id, semuel.pati@bppt.go.id, \\ muhamad.rodhi@bppt.go.id,nesha.adelia@bppt.go.id, bayu.samodra@bppt.go.id
}

\begin{abstract}
Biogas Power Plant (PLT) from palm oil mill effluent had been commissioned by a team from the Center of Technology for the Energy Resources and Chemical Industry, Agency for the Assessment and Application of Technology (PTSEIK-BPPT). The biogas power plant is located in PTPN V Kampar, Riau Province. A PLC (Programmable Logic Controller) has been implemented to support the operation of biogas power plant. Proper sensor selection has been done for each measurement applications. A computer and mimic panel are used as an interface for the operation of PLC. The master control system communicates with the slave control systems and Human Machine Interface (HMI) by means of ethernet communication protocol. Commissioning phase is carried out for 2 hours with a load of $450 \mathrm{~kW}$. Some process variable in biogas, such as fluctuation in methane concentration, pressures, and flow rate is measured in order to check biogas supply suitability with gas engine specification.
\end{abstract}

Key Words: Biogas Power Plant; Palm Oil Mill Effluent; Measurement and Control System and PLC

\begin{abstract}
Abstrak
Pembangkit Listrik Tenaga (PLT) Biogas dari limbah cair kelapa sawit telah diujicoba oleh tim dari Pusat Teknologi Sumberdaya Energi dan Industri Kimia, Badan Pengkajian dan Penerapan Teknologi (PTSEIK-BPPT). PLT Biogas ini terletak di Pabrik Kelapa Sawit (PKS) PTPN V Kampar, Provinsi Riau. Sebuah sistem instrumentasi dan kontrol berbasis PLC (Programmable Logic Controller) diimplementasikan untuk menunjang pengoperasian PLT Biogas tersebut. Pemilihan sensor yang cermat dilakukan untuk aplikasi pengukuran yang berbeda. Sebuah komputer dan mimic panel digunakan sebagai perangkat keras antarmuka pengoperasian PLC tersebut. Master sistem kontrol berkomunikasi dengan slave sistem kontrol dan perangkat komputer antarmuka (Human Machine Interface) dengan menggunakan protokol komunikasi ethernet. Uji coba PLT Biogas dilakukan selama 2 jam dengan beban sebesar 450 $\mathrm{kW}$. Sistem instrumentasi dan kontrol mampu mengukur variabel penting seperti fluktuasi kadar metana, tekanan, dan laju aliran dalam biogas untuk menganalisa kesesuaian spesifikasi pasokan biogas pada gas engine.
\end{abstract}




\section{Kata kunci : PLT Biogas; Palm Oil Mill Effluent; Sistem Pengukuran dan} Kontrol; dan PLC

Diterima (received): 02 Desember 2019, Direvisi (revised): 06 April 2020, Disetujui (accepted): 15 April 2020

\section{INTRODUCTION}

Indonesian palm oil has become one of their most important commodities in the world. Based on the data from FAO, between 20122016, Indonesia was ranked first in the world's largest palm oil exporter country with an average contribution of 22.31 million tons per year or $52.24 \%$ of the total world palm oil exports ${ }^{1}$. The high production of palm oil certainly has an impact to the amount of waste produced, such as liquid effluent or Palm Oil Mill Effluent (POME) which reaches $58 \%$ of the fresh fruit bunches processed total weight ${ }^{2}$.

POME's direct discharge to water stream can cause serious environmental damage without any further treatment. One of the common treatments for POME is open pond disposal. Consequently, methane gas is released from POME into the air that can cause global warming, which has 25 times greater impact than carbon dioxide ${ }^{3)}$. Despite its harmful nature, biogas from POME can be used to generate electricity where $1 \mathrm{~m}^{3}$ of POME can produce $17.1 \mathrm{~m}^{3}$ of methane equals to $30 \mathrm{~m}^{3}$ of biogas ${ }^{4)}$ and equivalent to of 8.5-10 W/hour electrical energy ${ }^{5}$.

A 700-kW biogas power plant is built in PT. Perkebunan Nusantara V (PTPN V), Kampar District, Riau Province to exploit biogas potential energy from POME. A Programmable Logic Controller (PLC)-based control system is implemented to support biogas power plant operation. This system is very useful to measure and control the important operating variable in order to increase the efficiency of biogas power plant.

Currently, the biogas power plant in Kampar is still in the commissioning stage. Electricity is produced as a result of gas engine's combustion energy from biogas feed ${ }^{6}$. Some of biogas parameters, like pressure, flow, and methane concentration need to satisfy gas engine requirements to a certain extent. Therefore, those variables need to be monitored by means of instrumentation. Some measurement is taking place at gas engine inlet pipe (for pressure and temperature), and also POME's and biogas process pipes. Any process variables deviation from setpoint will be minimized by the action of control system, so the stable operation of biogas power plant could be achieved ${ }^{7)}$.

Resistance Temperature Detector (RTD) measures temperature in the system, while pressure transmitter measures biogas pressure after passing the blower and on the outlet of dehumidifier. Two kind of flow meter are used in the system as biogas flow meter and POME flow meter. Biogas analyser is also installed to measure the concentration of the gas component in biogas.

A smooth control on process variable during operation is expected for efficient biogas power plant operation, by means of instrumentation and control system application.

\section{METHOD}

Specification of gas engine, including its instrumentation is being recorded prior to commissioning activity. Sensor/transmitter selection and control system structure configuration is also done in this activity. Then, after the commissioning activity is done, result of commissioning is analysed.

\section{Gas Engine Specification}

Gas engine specification is shown on Table 1. The selected model for this power plant is GE Jenbacher J320. Gas engine specification is recorded in order to check its suitability with biogas property. 


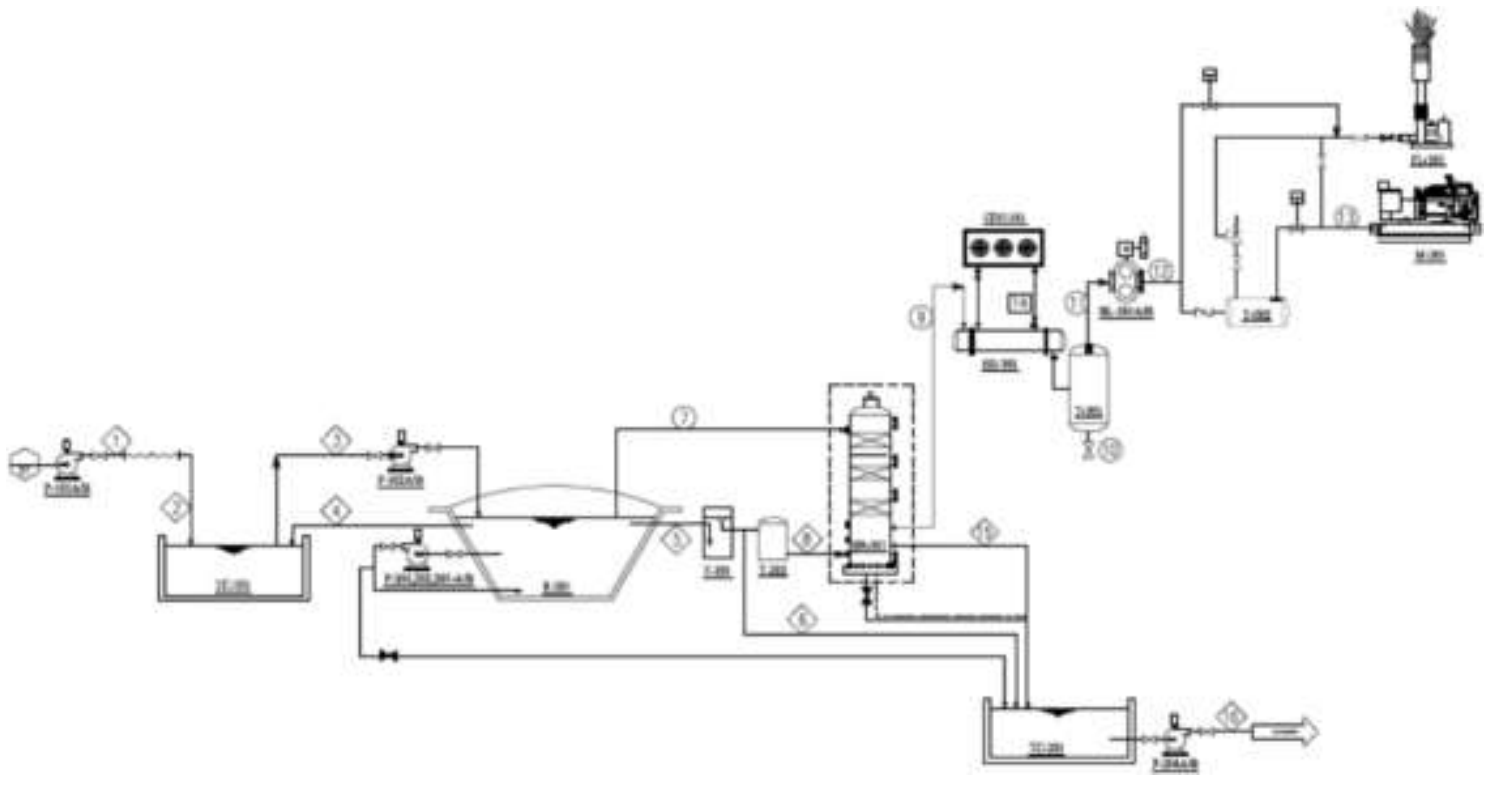

Figure 1.

Process Flow Diagram for Biogas Power Plant in Kampar

Source: Pasadena Engineering, Basic Engineering Design Data for Biogas Terantam

Table 1.

Gas Engine Specification of Biogas Power Plant in PTPN V Kampar

\begin{tabular}{cc}
\hline Model & GE Jenbacher JGS \\
& 320 \\
\hline Cylinder Configuration & V $70^{\circ}$ \\
Speed (rpm) & $1500(50 \mathrm{~Hz})$ \\
No. of Cylinder & 20 \\
Power (MW) & 1.063 \\
Efficiency (\%) & 40 \\
\hline
\end{tabular}

Source: GE Power \& Water, "Jenbacher Type 3", 2013

Maximum capacity of gas engine is 1.063 MW at full load, during operation stage, gas engine is planned to operate on $700 \mathrm{~kW}$. A summary of biogas specification for gas engine Jenbacher JGS 320 can be found in Table 2.

Table 2.

Biogas Specification for Jenbacher's Gas Engine

\begin{tabular}{lll}
\hline Parameter & Criteria & Limit \\
\hline Temperature & Minimum & $10^{\circ} \mathrm{C}$ \\
Lower Calorific Value & Maximum & $40^{\circ} \mathrm{C}$ \\
Hydrogen & $\begin{array}{l}\text { Rate of } \\
\text { changes }\end{array}$ & $<4 \% / \mathrm{min}$ \\
Gas Pressure & $\begin{array}{l}\text { Rate of } \\
\text { changes }\end{array}$ & $<10 \mathrm{mbar} / \mathrm{s}$ \\
\hline
\end{tabular}

Source: GE Power \& Water, "TA 1000-0300, Fuel gas and combustion air requirement”, 2015

\section{Sensor/Transmitter Specification}

Some process variables are being measured in this biogas power plant, such as flowrate of POME and biogas, biogas composition, gas engine's inlet pressure and temperature is being measured and controlled. Specification is summarized in Table 3.

Table 3.

Sensor/Transmitter Specification of Biogas Power Plant PTPN V Kampar

\begin{tabular}{|c|c|c|c|}
\hline Parameter & $\begin{array}{l}\text { Pressure } \\
\text { Transmitter }\end{array}$ & $\begin{array}{l}\text { Temp. } \\
\text { Transmitte }\end{array}$ & $\begin{array}{l}\text { Biogas } \\
\text { Flowmeter }\end{array}$ \\
\hline Range & $0-600$ mbar & $0-100^{\circ} \mathrm{C}$ & $\begin{array}{l}120-1200 \\
\mathrm{~m}^{3} / \mathrm{h}\end{array}$ \\
\hline Material & SS316L & SS316 & SS304L \\
\hline $\begin{array}{l}\text { Signal } \\
\text { Transmission }\end{array}$ & $4-20 \mathrm{~mA}$ & 4-20 mA & $4-20 \mathrm{~mA}$ \\
\hline $\begin{array}{l}\text { Power } \\
\text { Supply }\end{array}$ & 8-30 VDC & 8-30 VDC & 24 VDC \\
\hline Quantity & 2 pcs & 3 pcs & $1 \mathrm{pc}$ \\
\hline Parameter & \multicolumn{2}{|c|}{ POME Flowmeter } & Control Valve \\
\hline Range & \multicolumn{2}{|c|}{$0,3-15 \mathrm{~m} 3 / \mathrm{s}$} & $0-100 \%$ \\
\hline Material & \multicolumn{2}{|l|}{ SS316L } & SS304 \\
\hline $\begin{array}{l}\text { Signal } \\
\text { Transmission }\end{array}$ & \multicolumn{2}{|l|}{$4-20 \mathrm{~mA}$} & $4-20 \mathrm{~mA}$ \\
\hline Power Supply & \multicolumn{2}{|l|}{220 VAC } & 8-30 VDC \\
\hline Quantity & \multicolumn{2}{|l|}{$1 \mathrm{pcs}$} & 3 pcs \\
\hline
\end{tabular}




\section{Sensor Selection and Analysis}

Various sensors are being used in measurement and control system of this biogas power plant, such as temperature, pressure and flowrate sensors, Analysis of sensors, including its characteristics, suitability and advantages are being done for biogas power plant requirement.

\section{Biogas Analyzer}

Biogas composition, and concentration of other gas content is measured by biogas analyser. Qualitative measurement of biogas, such as methane number, also $\mathrm{CO}_{2}$ and $\mathrm{H}_{2} \mathrm{~S}$ concentration that can cause damage on gas engine is done by biogas analyser. Table 4 summarized the specification of biogas analyzer ${ }^{8}$.
Table 4.

Biogas Analyser Specification

\begin{tabular}{|c|c|}
\hline Measured Gas & $\begin{array}{l}\mathrm{CH}_{4}, \mathrm{CO}_{2} \text { and } \mathrm{O}_{2} \\
\mathrm{H}_{2} \mathrm{~S}, \mathrm{H}_{2} \text { and } \mathrm{CO} \text { (optional) }\end{array}$ \\
\hline $\begin{array}{l}\text { Measurement } \\
\text { Principle }\end{array}$ & $\begin{array}{l}\mathrm{CO}_{2}: \text { double infrared cell } \\
\mathrm{O}_{2}: \text { electrochemical internal cell }\end{array}$ \\
\hline Measurement Range & $\begin{array}{l}\mathrm{CH}_{4}: 0-100 \% \\
\mathrm{CO}_{2}: 0-100 \% \\
\mathrm{O}_{2}: 0-25 \% \\
\mathrm{H}_{2} \mathrm{~S}: 0-500 \mathrm{ppm}\end{array}$ \\
\hline $\begin{array}{l}\text { Sample Response } \\
\text { Time }\end{array}$ & $\begin{array}{l}\mathrm{CH}_{4}:<10 \mathrm{~s} \\
\mathrm{CO}_{2}:<10 \mathrm{~s} \\
\mathrm{O}_{2}:<20 \mathrm{~s} \\
\mathrm{H}_{2} \mathrm{~S}:<30 \mathrm{~s}(0-500 \mathrm{ppm})\end{array}$ \\
\hline $\begin{array}{l}\text { Sample Gas } \\
\text { Requirement }\end{array}$ & $300 \mathrm{ml} /$ minute \\
\hline Signal Transmission & $\begin{array}{l}6 \text { channel } 4-20 \mathrm{~mA} \text { (max), } \\
\text { Modbus RTU and relay } 24 \mathrm{Vdc} 6 \\
\text { Amp }\end{array}$ \\
\hline $\begin{array}{l}\text { Operating } \\
\text { Temperature }\end{array}$ & $\begin{array}{l}\text { W/ heater: } 0-50^{\circ} \mathrm{C} \\
\text { w/o heater: }-20-50^{\circ} \mathrm{C}\end{array}$ \\
\hline Operating Pressure & $0-350 \mathrm{mbar}$ \\
\hline Process Connection & 1/4" FNPT Swagelok \\
\hline Power Supply & $110-230 \mathrm{VAC}, 50-60 \mathrm{~Hz}$ \\
\hline Power Consumption & $155 \mathrm{~W}$ (max) \\
\hline $\begin{array}{l}\text { Source: Geotech. } \\
\text { Specification. DS 06, }\end{array}$ & gas 3000 \\
\hline
\end{tabular}

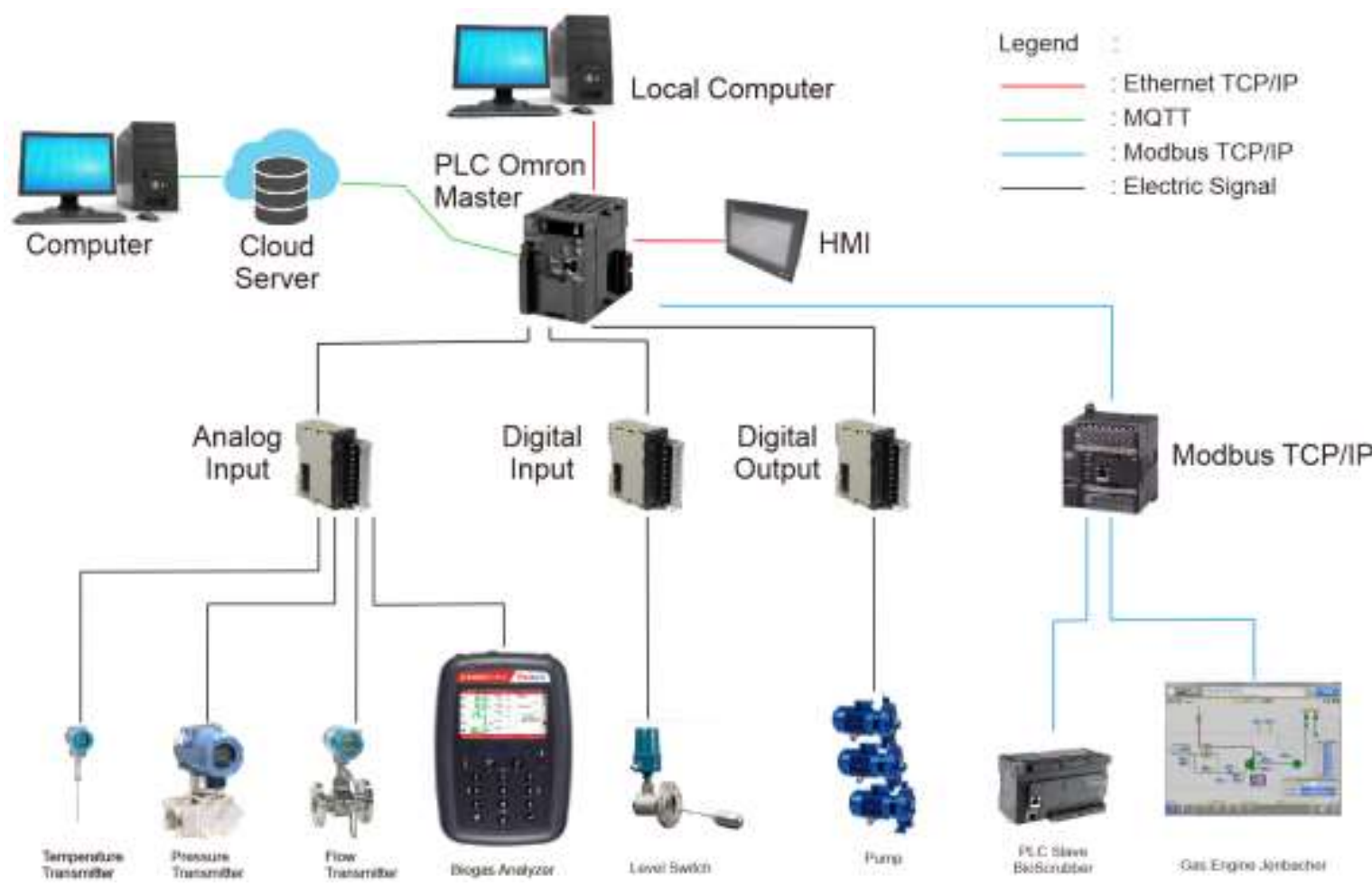

Figure 2.

Control Structure of Biogas Power Plant, PTPN V Kampar 


\section{Control Structure}

Control structure configuration is shown in Figure 2. Slave station of bio-scrubber package system and gas engine control system is being set up by their respective company packagers, such as Bio-clean (of bio-scrubber) and General Electric (of gas engine). The in-house design of measurement and control system includes the local computer (for human machine interface), and master station of Omron CJ2M PLC, equipped with analogue, Modbus module and digital inputs. TCP/IP Modbus communication is established between master station and its slave stations. Process variable monitoring, including gas engine's exhaust temperature, power output, and daily report, also data acquisition and control is achieved with this scheme. Analog input module is used for measuring field's process variables, such as temperature, pressure and flowrate with 4-20 mA transmission signal. Digital input and output module are used to monitor pumps and engine operating status from MCC (motor control centre). This control structure is also equipped with MQTT (message queueing telemetry transport) that used for remote process monitoring from Serpong office.
Biogas feeding into gas engine is being controlled by the master station. Steady supply of biogas at rated pressure from reactor is required for gas engine operation. Consequently, pressure control is required to maintain biogas supply into gas engine at 200 mbar. Biogas overpressure will be diverted to flare and burnt to minimize pollution effect.

Pressure control is achieved by manipulating blower's rotation speed and control valve's action, thus varying biogas pressure after dehumidifier to gas engine inlet.

A control scheme is applied to the system so that if the pressure inlet is exceeding 200 mbar, control valve will be opened automatically to relieve the pressure and burn biogas in flare. In reverse, if the pressure is under 200 mbar for 5 seconds, then the valve will be in closed position.

\section{Commissioning Phase}

Process variables are being measured, recorded and controlled in order to support commissioning activity in biogas power plant PTPN V Kampar. Commissioning is executed for 2 hours and $450 \mathrm{~kW}$ load.

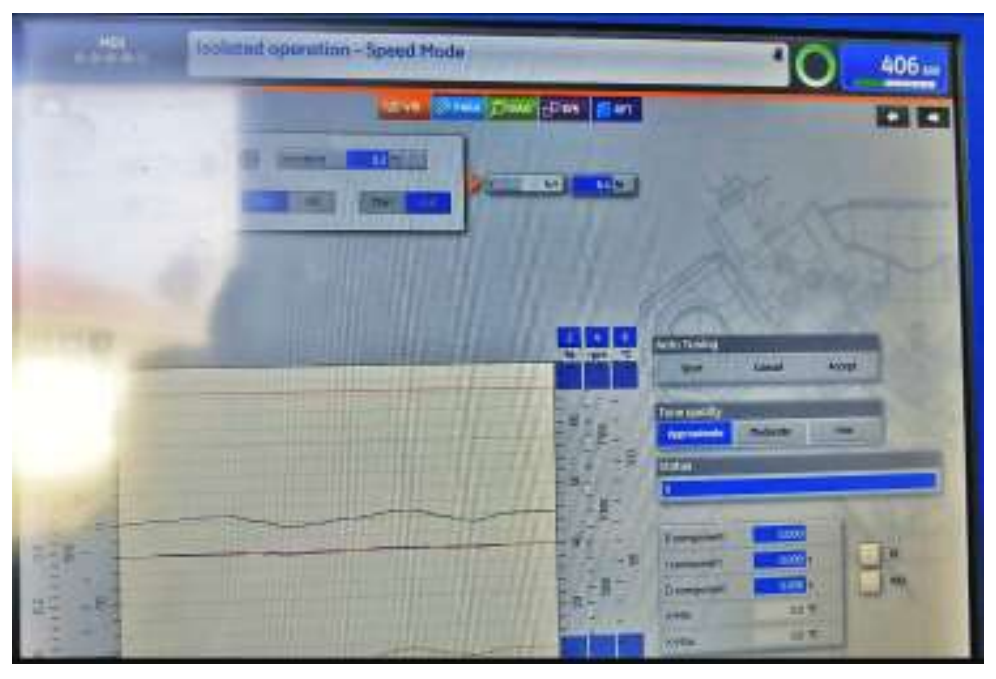

Figure 3.

Commissioning of Biogas Power Plant, PTPN V Kampar

\section{Commissioning Analysis}

Various parameters, such as gas engine power, blower frequency, also biogas methane number, inlet pressure and flowrate will be analysed after commissioning phase in order to check the suitability of biogas specification with gas engine. Deviation occurred during commissioning will be known, and corresponding recommendation or action will be made necessarily for smooth operation in the future. 


\section{RESULT AND DISCUSSION}

\section{Sensor Type Selection Analysis}

Several types of sensors, including temperature sensors, pressure sensors, and flow rate sensors is used in this project. RTD (Resistance Temperature Detector) type is used as temperature sensor. RTD will change the amount of temperature into resistance, the greater the temperature, the greater the resistance. Some edges of RTD sensor to another is their higher accuracy and stable measurements. It is also does not need special cable for connection ${ }^{9}$. In general, RTD can be used for smaller temperature ranges application such as biogas plant. The maximum temperature in POME waste is $80^{\circ} \mathrm{C}$, in reverse, the minimum temperature measured is $12^{\circ} \mathrm{C}$ in dehumidifier output temperature. Therefore, RTD can be chosen as a temperature sensor on a biogas power plant. The temperature measurements are carried out at 3 points which is located before POME entering the mixing pond, dehumidifier outlet line, and gas engine inlet.

Biogas pressure at the dehumidifier outlet and gas engine inlet is measured by pressure transmitter. Due to gas engine's membrane strength limitation, biogas pressure shall not exceed 200 mbar. Therefore, it is important to measure gas engine's inlet pressure before biogas enters the gas engine. The measuring range is sufficient to measure biogas operating pressure.
Two kind of different flowmeters are used for different application in this project. Vortex flowmeter, which uses the vortex principle, is used to measure biogas flowrate and electromagnetic flowmeter is used to measure POME fluids. Electromagnetic flowmeter is one of the options for measuring wastewater fluids, such as POME, among other flowmeters. It is widely claimed for having more accuracy and repeatability. It's another advantage is no moving part, thus minimizing problems such as erosion and corrosion from waste water. Electromagnetic flowmeter also has more protection in the coating, so it can protect the measuring instrument from corrosive flow ${ }^{7}$. Vortex flowmeter is used to measure biogas flowrate. The advantage of vortex flowmeter compared to other flowmeters is that it can measure the volume of biogas without being affected by the biogas composition, due to its pressure and temperature measurements feature that corrects volumetric standard value. Another additional feature is a totalizer that calculates the quantity of gas volume that has passed through vortex flowmeter ${ }^{10)}$.

A transmitter is connected to each of RTD temperature sensor which converts change of resistance from the RTD to an electric current of 4-20 mA. All transmitter sends this electric current to PLC analogue input module as an input signal. Two wire schemes are used for temperature and pressure transmitter, a 4-20 $\mathrm{mA}$ electric current is superimposed to the 24 VDC power supply cable from the transmitter, so that the signal transmission and power supply are on one cable for each transmitter.

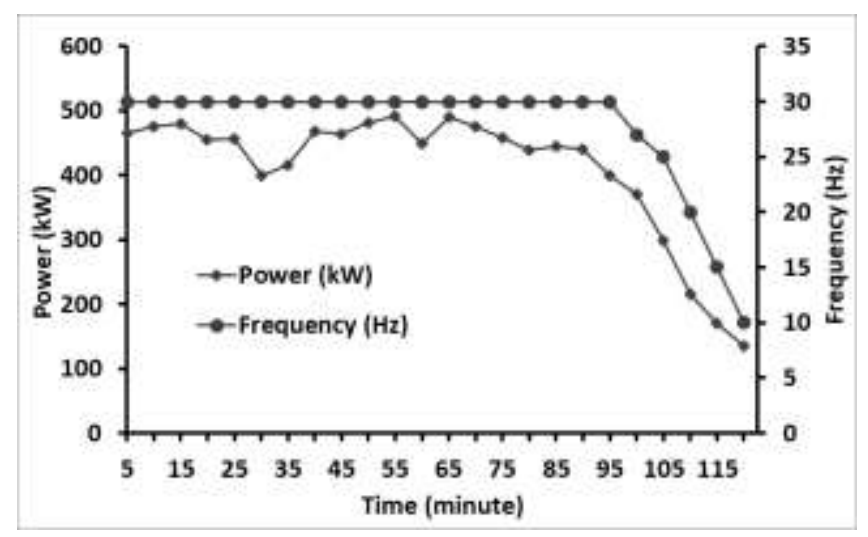

Figure 4.

The Relationship Between Blower Frequency and Gas Engine Electric Power

\section{Test Result Analysis}

Commissioning trial run of the biogas power plant is carried out within 2 hours with a load of $+/-450 \mathrm{~kW}$. Biogas is supplied from the reactor (covered lagoon) by using a blower to the gas engine. The biogas flow rate is supplied according to gas engine requirements by modulating blower frequency so that the biogas flowrate increase by increasing frequency of the blower by using variable speed drive (VSD). The relationship between blower frequency and gas engine electric power depicted in Figure 4. 
It can be seen in Figure 4 that the gas engine operating points floats around $450 \mathrm{~kW}$, with a blower frequency $+/-30 \mathrm{~Hz}$. When the load at the Tandun Kernel Oil (PKO) Plant reduced, its power will decrease. The blower frequency can be changed manually by inputting the desired value on the HMI screen. When the blower frequency is lowered, the power will also decrease. The biogas supply rate in the gas engine is directly proportional to the gas engine electric power requirements, the greater the power required, thus leads to greater biogas flow rate requirement. Therefore, biogas frequency shall be increased as well, as shown in Figure 5 which shows the relationship between biogas flowrate and gas engine electric power to time.

As seen in Table 2, one of gas engine feed requirement is the gas pressure fluctuations rate shall not exceed 10 mbar per second.
Figure 6 shows the change in engine gas inlet pressure with time. Biogas inlet pressure rate of change is below 10 mbar per second. It requires around 10 to 15 minutes for 10 mbar differential pressure in biogas inlet. Likewise, methane concentration is very stable and tends to operate in 56.8 - $57 \%$ over time. Methane number itself is a product of gas engine PLC's algorithm calculation, by using input such as methane number curves, and other hydrocarbon properties. When the PLC indicating a problem in methane number variation, it will send an alarm or warning to the HMI screen system, to alerting the operator. Thus, the fluctuations in the gas inlet engine pressure have met the specifications required in Table 2, while it can be inferred from the graph that biogas methane concentration is stable.

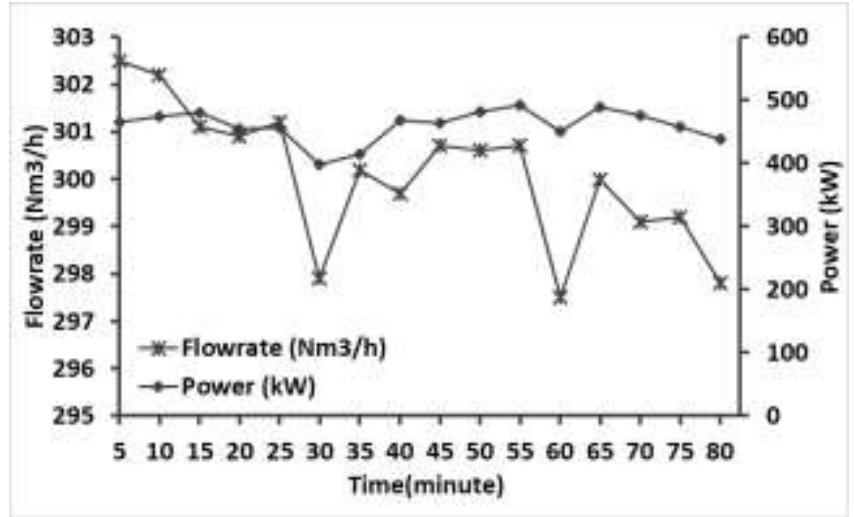

Figure 5.

The Relationship Between Biogas Flowrate and Gas Engine Electric Power

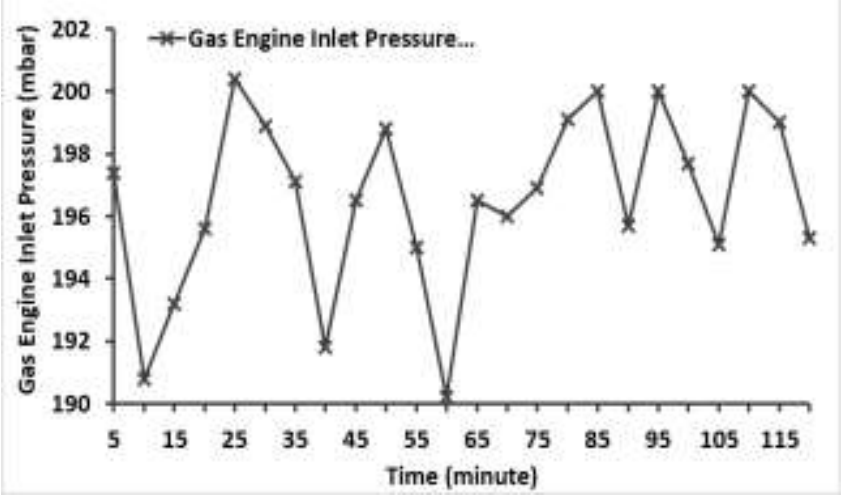

Figure 6.

The Flowrate Changes of Gas Engine Inlet Pressure With Time 


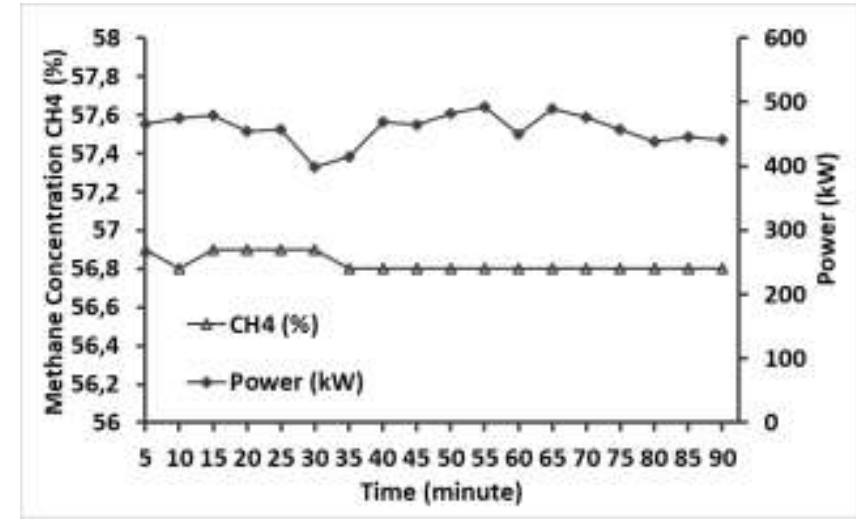

Figure 7.

The Relationship Between Methane Concentration and Gas Engine Power with Time

\section{CONCLUSION}

The instrumentation and control system, that consist of pressure and temperature transmitters, biogas analyser, and POME flowmeter connected to the PLC along with its subsystem, is applied to the Biogas Power Plant in PTPN V Kampar. The system is able to monitor biogas power plant operation during commissioning, by measuring important process variables such as pressure, gas engine power, biogas flowrate and methane concentration. Pressure inlet in the gas engine during two hours commissioning trial run is complied with gas engine requirements, while methane concentration is proved stable over operation time.

\section{ACKNOWLEDGEMENT}

The authors would like to express their massive gratitude to Ministry of Research and Technology (Kemenristekdikti) which has supported the Program of National Innovation System Research Incentives (INSINAS) Flagship Biogas, PT. Perkebunan V and WP 3.4 team who have supported this research.

\section{REFERENCES}

1. Indonesian Ministry of Agriculture, Outlook Komoditas Pertanian Subsektor Perkebunan Kelapa Sawit, Pusat Data dan Sistem Informasi Pertanian Sekretariat Jenderal Kementerian Pertanian, Jakarta, 2018.

2. Erliza, H., Rivai, M., The Potential of Palm Oil Waste Biomass in Indonesia in 2020 and 2030, IOP Conf. Series: Earth and Environmental Science, Vol. 65, 2017, p 25.

3. Aiyen, Edy, S., Erliza, H., et. al., Roadmap Riset Kelapa Sawit Indonesia, Badan Pengelola Dana Perkebunan Sawit (BPDP Sawit), Jakarta, 2017.

4. Rahayu, A., Karsiwulan, D., et. al., Buku Panduan Konversi POME menjadi Biogas Pengembangan Proyek di Indonesia, Winrock International, Jakarta, 2015.

5. Tabassum, S., et. al., An Integrated Method for Palm Oil Mill Effluent (POME) Treatment for Achieving Zero Liquid Discharge - A Pilot Study, Journal of Cleaner Production, Vol. 95, 2015, p148.

6. Mel, M., Yong, A., et. al., Simulation Study for Economic Analysis of Biogas Production from Agricultural Biomass, Conference and Exhibition Indonesia New, Renewable Energy and Energy Conservation, 4-6 June 2014, Jakarta, p 204-214.

7. $\mathrm{ABB}$, Achieving accurate wastewater flow measurement, Gaining an enhanced overview of wastewater flows using ABB's WaterMaster, AD/Flow/006-EN Rev. A, 2019.

8. Geotech, Biogas 3000 Technical Specification, DS 66 Issue 02, 2016.

9. Kiker, E., Automation Basics: Thermocouples versus RTDs, InTech Magazine, 2013.

10. ABB, $A B B$ Vortex flowmeter - Metering Gas in Biogas Plants, Application Description AG/PS109-EN, 2012. 